\title{
MAHMUDKHODJA BEHBUDI AND THE ISSUE OF NEW UZBEK LINGUISTICS
}

\author{
Zaynabidin Abdirashidov
}

Article DOI: https://doi.org/10.36713/epra5168

\begin{abstract}
One of the leaders of Turkestan Jadid movement Mahmudkhodja Behbudi ran a wide range of activities. He was first to be engaged in science among new Uzbek educated men despite his career in editorial, publication and journalism. His school textbooks, scientific articles, in particular his views on linguistics were clear indication of his achievements in this sphere of science. In his articles devoted to languages Behbudi paid attention to the pressing issues of modern linguistics and he put forward his ideas worth considering in this field of science. An analysis of Behbudi's articles in this area shows that he conducted a number of studies in dialectology, sociology, and cultural anthropology.
\end{abstract}

KEY WORDS: Behbudi, Jadidism, linguistics, literary language, dialect, cultural anthropology, reformist movement.

\section{INTRODUCTION}

At the end of the 19th century and the beginning of the 20th century, the reform movement spread throughout the countries of the East and spread to Turkestan, which was under the control of the Russian Empire. This reformist movement was named differently across regions. In the Arab world it was called "An-Nahda" (Renaissance) and in the history of the Turkic peoples in the colonies of the Russian Empire it was given the name of Jadidism. The word Jadid literally means "new." Jadidism began in the Crimean Baghchasaray in 1883 with opening a newmethod school by Ismail Gasprinsky.

The Jadid movement is one of the relatively short but very intense and complex periods in the socio-political, cultural and enlightenment history of the Turkic peoples under control of the Russian Empire. The essence of this movement has been studied and analyzed differently in various periods. The scale of Jadidism, the lives and works of those who initiated it and its impact on society have not yet been fully explored in researches. This, in turn, requires the study of the Jadid movement in its entirety.

\section{LITERATURE REVIEW}

The twentieth century began with some success for the peoples living in the territory of the Russian Empire. After Russia was defeated in the war against Japan, it was unable to withstand the pressure of internal and external forces. Political struggles within the Empire began to escalate, and by the end of 1905 the Emperor was forced to declare a Manifesto giving freedom to all political forces and groups. One of the main points of the manifesto was freedom of speech.

Turkestan Jadidism emerged much later than in other Muslim regions of the Russian Empire, in the early twentieth century. Some scholars who study Turkestan Jadidism point out that local Jadids did not have a common program until 1917. According to them, Abd al-Rauf Fitrat's (1886-1938) Munazara (Debate) and Hind Sayyahi (Indian Traveller), which changed the worldview of inhabitants of Turkestan, were considered an unofficial program of Turkestan Jadids until 1917. [6: 95-96] The same idea was put forward by the Japanese scholar Hisao Komatsu and he states that above two works by Fitrat were a manifesto of the Jadid - reformist movement in Bukhara and Turkestan. [2: 279] 


\section{SJIF Impact Factor: 7.001| ISI I.F.Value:1.241| Journal DOI: 10.36713/epra2016 \\ EPRA International Journal of Research and Development (IJRD)

These assertions and definitions are, of course, relative in determining the nature and direction of Turkestan Jadidism. Prior to the publication of Fitrat's Munazara and Hind Sayyahi in 1911, the activities of the Turkestan Jadids had reached a certain stage, they had achieved great success in spreading new schools of thought, and most importantly, had established a national press in Turkestan.

Adeeb Khalid, an American historian who has studied the foundations of Turkestan Jadidism, sees its emergence as a modern "response" to modernity as a result of the transformation of Central Asian society and the Russian invasion and its efforts to redistribute the world, including the Islamic world. Through the spread of Jadid enlightenment, Khalid sought to distinguish the Turkestan Jadids and their followers, who sought to create a "modern and at the same time a new elite committed to Islam and loyal to Turkestan" [1:218] and as a result ready to defend the region's interests in the modern world. According to Khalid, Turkestan Jadidism often denied the views of the Crimean and Volga-Ural Tatars and tried to find ways to adapt to the realities of the region in school work, literary language and other issues. [1:23, 181-182, 262-328]

However, it should be noted that the Turkestan Jadids relied more on the views and ideas of the Muslims of Inner Russia, especially the Crimean Tatar Ismail Gasprinsky, the founder of the Jadid movement, in resolving important issues.

According to Begali Kasimov, Jadidism is not a stream, but a movement. It is a social, political, enlightenment movement. Because this movement:

1) was able to involve all segments of society in the reform process;

2) carried out political activity on the way to national independence;

3) was able to direct education and culture, the press to socio-political goals. [7:6]

\section{ANALYSIS}

In Turkestan, the so-called Jadid intelligentsia was formed in the first decade of the twentieth century. The basis of this group was the enlighteners of Tashkent, Samarkand, Bukhara and Kokand. Munavvarqari Abdurashidkhanov and Abdulla Avloni in Tashkent, Mahmudkhodja Behbudi and Abdulkadir Shakuri in Samarkand, Sadriddin Ayni, Fitrat and Usmankhodja in Bukhara, Ashurali Zahiri and Mahmudjan Abidov in Kokand were at the center of this Jadid group.

Mahmudhodja Behbudi was one of the people who played an important role in the formation of the Jadid movement in Turkestan and contributed to the spread of Jadid ideas in Turkestan with his thoughts and practical actions.

Behbudi first set out for the Hajj pilgrimage in 1899 and visited cities such as Istanbul and Cairo, the capitals of the Muslim East. Adeeb Khalid noted that during the same trip, Behbudi had the opportunity to observe the reforms and innovations in the field of public education in the Ottoman Empire and Egypt, as well as to communicate with those who led the reforms in the social sphere. Eight months later, upon his return to Samarkand, he subscribed to the Tarjuman newspaper. [1:80]

Behbudi's work is multifaceted, and he stands out among the Jadids of Turkestan for his effective work in the fields of education, journalism, politics, and social issues. And, if one examines the aspects of this activity, it becomes clear that Mahmudhodja Behbudi was the leader of the Turkestan Jadids. In his multifaceted work, language, especially literary language, as well as the issue of language learning occupies a special place. Of course, Behbudi, in his articles for various periodicals in any field, tried to write in a language that he considered a "literary language" for the Turkestan region. At this point, it is important to clarify Behbudi's position on the issue of a common language or literary language, as well as on the issue of "common literary language", which was very relevant for that period.

At the end of the 19th century, more precisely, from 1883, ie from the first issue of the newspaper Tarjuman, Ismail Gasprinsky proposed the creation of a common literary language for the Turkic peoples, in the words of Ingeborg Baldauf, "dialect of reconciliation" [3:38]. Gasprinsky's efforts to create a "common language" for the Turkic peoples can be considered as a product of his concept of "nation" and "nationality" and the interpretation of this concept. In his numerous articles on language, Gasprinsky focuses subscribers' attention on understanding the concept of "nation" above. According to him, "a nation is a union of religion and language. If one of these two things is lost, the nation loses its identity" and faces a crisis. [9] Gasprinsky stressed that the past and future of all nations are based on religion and language. As important as the unity of religion is, the unity of language in literature is just as important and a direct means of development. [4] In order to show the great importance of language unity, Gasprinsky even raised it to the level of the beginning and foundation of all other units. [5]

From this point of view, Behbudi was the first among the Turkestans to widely promote and support the idea of linguistic unity by Gasprinsky. Behbudi also conducted a special survey and experiment on this issue in the cities of Turkestan. In this respect, we also discover Behbudi as the first sociologist among Turkestanies. During his sociological research, Behbudi read out various newspapers to ordinary people who did not read newspapers at all and did not know the language of other Turkic peoples and thus gathered opinions on 
the "language" of the newspapers read from different parts of Turkestan, and gave general conclusions. On the basis of his experience and survey Behbudi concluded that the language of Gasprinsky's Tarjuman newspaper, the language of the journal Mir'at and newspaper Ulfat which issued by Abd alRashid Ibrahimov (1875-1944) in Saint-Petersburg, were easier to understand for the population of Turkestan. And he recommended that "all editors in Russia need to follow in the language of $\mathrm{Mr}$. Ismailbek, the chairman and father of our new press, who has served our nation for a quarter of a century with his language, pen and heart." In this way, Behbudi, like Gasprinsky, emphasizes that the unity of Russian Muslims should be based on language unity. [18]

Continuing his thoughts on a single, universal language, Behbudi said, “... the benefits of language unity are very well known. After all, language unity is the basis of friendship, love, mutual assistance and cohesion." He gave example samples from Mawlana Rumi's verses in his book Masnaviy-i Ma'navi on language. [10]

For Turkestan, Behbudi promotes the "middle dialect" of the Persian language, along with Turkic. The practical result of this proposal is the journal Ayina, published by Behbudi in Samarkand between 1913 and 1915. Baldauf sees Behbudi's initiative as an expression of solidarity with its readers. [3:40]

In Turkestan, the issue of bilingualism was raised by Behbudi in an article sent to the Tarjuman in 1909, long before the publication of Ayina. Behbudi wanted to emphasize the importance of Turkic and Persian for inhabitants of Turkestan and argued that he was in favor of the inclusion of both languages in school education. Behbudi tried to prove his point with the following arguments:

1) most of the urban population in Turkestan can speak Turkic and Persian fluently;

2) in some areas a mixed form of these two languages is used;

3) applications to official bodies are written in Turkic;

4) shari'ah fatwas are written in Persian and recorded in Turkic, and this method is applied throughout Turkestan.

At the end of Behbudi's article, based on his own evidence and proof, he concluded that it was appropriate to teach both Turkic and Persian in Turkestan schools. [11]

Behbudi stated that he learned the (common)Turkic language through the Tarjuman newspaper, he further added that "my mother tongue is Persian, and I learned the Turkic I write from the pages of the Tarjuman which is my spiritual teacher." [11] This indicates that the (universal) literary or (general) Turkic language proposed by Gasprinsky was created. The attention to Gasprinsky's Tarjuman newspaper in Turkestan can be seen in the fact that "schools that were reformed and opened under the name of usul-i jaded, taught Turkic from beginning to end under the influence of the respected Tarjuman and contributed to the spread of Turkic in Turkestan." [11] These words also belong to Behbudi. According to Behbudi, the activity of Gasprinsky and the newspaper Tarjuman had a great influence in Turkestan. Behbudi noted that "all teachers, masters and mentors in Turkestan have learned the Turkic language with the help of the Tarjuman" and have been able to get acquainted with "modern new literature" and met their "cultural needs" which has been there for a quarter of a century through the Tarjuman. [11] When Behbudi refered to the Common-Turkic literary language, he meant the language proposed by Gasprinsky.

Begali Kasimov noted that the Muslims of the empire, in particular, were in the same circle as Behbudi and Gasprinsky in the struggle for the accession of Turkestan to the ranks of a developed nation and ultimately for independence. This was the "compromise path" proposed by Gasprinsky, which sought to achieve enlightenment through the achievements of the Russians and their culture, and, most importantly, not to lose national identity in this way. [8:42] The views of Behbudi on learning Russian language and promotion of Russian culture can be found in many of his articles. [15] In particular, in his article We Need Four Languages, Not Two [12], published in the first issue of Ayina journal, he states that people of Turkestan need to be fluent in all the four languages of Turkic, Persian, Arabic and Russian in order to keep pace with the times and enjoy modern knowledge and ideas. It was emphasized that they should reach the level of fluency. In this article, when Behbudi refered to the Turkic, he meant Uzbek language which was spoken by the majority of the local population. According to him, the reasons for learning these four languages were:

1) Turkic or Uzbek - the language spoken by the majority of the people of Turkestan;

2) Persian is the language of madrasa and writers. To this day, Persian poetry and prose books have been taught in old and new schools all over Turkestan;

3) Arabic - all Shari'a books taught in madrassas are in this language;

and 4) Russian - to study modern science, which is useful for "modern commercial work, industrial and national affairs, and even the religion of Islam and the service of the nation".

Behbudi pointed out the factors that lead to the study of the language, emphasizing that it is "a blessing for us" that either Turkic or Persian was the mother tongue for the local people, and that every Turkic people inhabiting in the region knew these languages well "without education". He further noted 


\section{SJIF Impact Factor: 7.001| ISI I.F.Value:1.241| Journal DOI: 10.36713/epra2016

that "Those who know these languages fluently can enjoy the works of Firdavsi, Bedil, Sa'di, Masnavi written in Persian, as well as the works of Fuzuli, Navoi, Baqi, Sami, Abd al-Haq Hamid, Akrambek, Sanayi, Nabi, Naji written in Turkic, and translations of works by Tolstoy, Jules Verne and other modern authors in Turkic".

Why did Behbudi want inhabitants of Turkestan to focus on learning Russian? According to him, in order for the nation not to be completely annihilated by other nations, they must act side by side, along with other developed nations, both commercially, industrially and politically. There was no one among the people of Turkestan who was able to speak in Western languages, including Russian, from the rostrum, even for the benefit of the nation and the homeland. In order to eliminate these shortcomings, it was necessary to learn the Russian language, study at Russian universities and be aware of all the laws. Behbudi raised the issue of language learning as a political issue and wrote that it would pave the way for the formation of intellectuals capable of serving for the interests of the Motherland.

Behbudi also raised the same issue in his review for Abd al-Rauf Fitrat's Munazara on how it was important to learn Russian for peoples of Turkestan. [15] Behbudi also cited a hadith (narrative) that even the Prophet (peace and blessings of Allah be upon him) commanded people to learn foreign languages, which was the main proof that the people who were to learn this language would not become "kafir." [12]

Behbudi's views on literary language were reflected in his article published in 1915, Til Masalasi (The Problem of Language). This article consisted of two parts, in the first part Behbudi discussed the dialects of the Turkic language. According to him, the sub-types and dialects of the Turkic language, which were widespread in Turkestan, were influenced by Persian culture and literature for hundreds of years, during these years so many words were borrowed from Persian, and the original Turkic words were forgotten and were out of use during this time. Also, since the 14th century, countless words have entered the dialects of the Turkic language from Arabic, which is the language of sacred religion of Islam and the language of the Qur'an, and it is impossible to exclude them from the dialects. Because there is no alternative to such words.

Behbudi said that the language of the Turkic peoples living in different regions was influenced by Persian and Arabic to the same extent as the language of the people of Turkestan, some of which even took Persian and Arabic so much that their languages were combined with Turkish, Persian and Arabic and this language was called "Ottoman language". Speaking of the Ottoman language, Behbudi emphasized that in order to write and read fluently in this language, one must be "familiar with the literature and rules of the three languages", otherwise "most of the works written in Ottoman dialect" would be incomprehensible not only to the "people with basic literacy", but also for some intellectuals.

As Behbudi wrote about language dialects in Turkestan, he presents himself as a mature linguist. Behbudi studied the extent to which the dialects of the languages of peoples of Turkestan were influenced by Persian and Arabic, depending on the region in which they lived, and the process was "not of the same everywhere, but of different varieties depending on geography". And no matter how much the Turkic language has changed under the influence of other language, he concluded that "everyone who spoke a dialect of a Turkic language could understand each other". This shows that Behbudi also had a deep knowledge of dialectology.

Speaking about the language of books, in other words, literary language which is widespread in Turkestan, Behbudi said, "In Turkestan, Bukhara and Khiva, even if everyone writes according to their own dialect, they are near (close) to each other", in other words, "the educated" or the intellectuals share literary language and have "language unity". [14]

The second part of the article Til Maslasi was devoted to the issue of creating a single, simplified literary language for the Turkic peoples. Behbudi said he had tried to take a "neutral" approach to the issue. Behbudi began by analyzing the path traversed by the Volga Tatars, the peoples of the Caucasus, to show the difference between dialect and "literary language". According to him, the "language" of the press published by Tatars and Azerbaijanis is "much higher" than the "street language", which is known to every intellectual who reads the newspaper. Even the language of the newspaper Waqt and the journal Shura from the year of their publication, "if the past issues are to be compared to the present ones, the current ones seem to be more formal' which means the language was in constant "progress". Indeed, Behbudi's conclusion about the language of the Tatar and Azerbaijani press shows that he did some research, studies, observations and analysis in this area. And this, in turn, proves once again that Behbudi was a mature linguist who, in addition to constantly monitoring the Turkic language press, had been able to draw definite conclusions by analyzing how their language policy was changing.

As mentioned above, Behbudi conducted a sociological survey to reach such a conclusion, and the results of his research to determine which language of the press was understandable to the average person from Turkestan are reflected in the second part of the article Til Masalasi. Indeed, Behbudi's researches and studies should be viewed in terms of expressing his views on the creation or adoption of (common) literary language, which was 


\section{SJIF Impact Factor: 7.001| ISI I.F.Value:1.241| Journal DOI: 10.36713/epra2016

one of the most important issues at the time as he had his own position.

Although Behbudi supported the idea of simplifying the language in the matter of general literary language and bringing it into a form that is understandable to the public, he considered the issue of purifying the language, that is, finding alternatives to Arabic and Persian words and applying them to the language, to be "impossible to put into practice, nothing more than a hollow dream". At the same time, Behbudi touched upon the issue of the use of new words from other languages in newspapers and magazines in any form, and as he explained the reason behind this issue, he stated that "It is due to the lack of organizations and people who can invent Turkic new names for the things which have been made or invented and called in foreign languages in the age of science and crafts development'. Here, Behbudi brought the need to establish a scientific society which should have organized borrowings to the agenda.

Analyzing the articles in the newspaper Sada-yi Turkistan on the issue of language purification, Behbudi called this act of the newspaper as an "impossible dream to implement". The reason is that if we try hard to purify the Turkic language, which has been under the influence of Arabic and Persian for centuries, to "get rid of the borrowings from these languages, then we will have to spend some more thousand years, an eventually once the effort has come to an end, new words from more advanced nations' languages start to penetrate into our mother tongue". Behbudi had taken such a position on the issue of language purification.

As Behbudi was concerned about simplifying the language, he suggests that plural forms should be written in Turkic form while using arabic words, for example, while writing the words such as, "ulum, funun, ulamo, quzzot and ..., the forms should be changed into fanlar (ologies), ilmlar (sciences), olimlar (scientists/scholars), qozilar (kadis/religious judges) instead", and he further suggested that complex sentences used in the press such as "kurrai azrda yashamakda bo'lgan har millatning o'ziga maxsus bir lisoni milliysi vordur (all the nations living in the spheric land do have their special language - means of national communication)" should be simplified as much as possible in Turkic. However, as mentioned above, Behbudi was firm when he stated "to think of alternative Turkic names for all scientific and religious terms and phrases is nothing more than exhausting oneself and wasting the press".

Behbudi believes that a simple language was necessary to "talk to the people around", while literary and scientific language was necessary to "know and use existing science and history". In his view, given that a simple language which is a dialect, would vary by region, thus, this language could not be considered literary, and there was no point in using it as a literary language either. In addition, Behbudi considered Turkestan dialects to be "incapable" of being a literary language. The reason for Behbudi's conclusion was that in order for "scientific and literary, it should be used by the mothers of every village and street", just as the mothers of other developed nations who are educated "from birth to birth". Therefore, Behbudi concluded that "since we need science and knowledge, some branches and dialects of the Turkic language have all kinds of modern, scientific, religious, historical books, we should try to read and understand them".

As mentioned above, the main reason for Behbudi's sociological survey and research on which newspaper language the common people of Turkestan understood and accepted was to raise the language of the newspapers Tarjuman or Ulfat to the level of (common) literary language. Behbudi explained his view as follows: "In order to be aware of science of the world, one must know one of the languages of Russian, German, French, English, Italian, Arabic or Japanese, and if one does not know any of them, s/he should be familiar with Caucasian or Crimean dialect literature to be aware of the world."

\section{IV.DISCUSSIONS}

Behbudi's views on literary language caused great opposition in his time. One of his closest allies, Haji Muin, had opposed his views on literary language. Hajji Muin advocated the purification of the local language and its formation as a literary language by purifying it from foreign (Arabic and Persian) words. [19] Moreover, the duality proposed by Behbudi, that is, the idea of using Persian as well as Turkic in the whole of Turkestan, was not supported by Haji Muin. Ingeborg Baldauf points out that Haji Muin was only partially able to put his ideas into practice when Behbudi was on a trip when he was appointed as a temporary editor of magazine Ayina. According to Baldauf, Haji Muin managed to turn the bilingual magazine Ayina into a purely Turkic-language magazine in a short period of time. [3:44]

At the end of Behbudi's article Til Masalasi he emphasized that no language can develop only with its own vocabulary, but can be developed by adopting new words from other languages, instead of wasting time refining the language by noting "let's get ready for the future, not for the past'. He also pointed out that it was not expedient to write literary works in these dialects, as there were differences between the dialects of different regions of Turkestan. Behbudi saw the illiteracy of mothers as the main problem and obstacle to the creation of a (common) literary language. In order to create a literary language, according to Behbudi, first of all, "we must first teach our mother and teach her the 


\section{SJIF Impact Factor: 7.001| ISI I.F.Value:1.241| Journal DOI: 10.36713/epra2016

language". Behbudi stressed that the development of literary language and science depends on the knowledge of the mothers of the nation. On the one hand, he raised the issue of letting more girls to schools and making them literate, and on the other hand, using as few Arabic and Persian words as possible to create a literary language. He suggested writing simply with extensive exception of other Turkic languages. [14]

Among the articles published by Mahmudkhoja Behbudi on linguistics, his views on the word sart are of great importance from the point of view of modern linguistics. An analysis of these articles reveals that Behbudi was one of the first of his contemporaries to deal with the etymology of the word, to conduct research, and, in modern parlance, to speak as a cultural anthropologist.

In the article Sart So'zi Majhuldir (The word Sart is abstract) published in the magazine Shura [16], Behbudi used the word sart, which was introduced by the Russians to the local population, whether it existed in various dictionaries, how the surrounding nomadic peoples used the word, etc. he cited 24 uses of the word, and finally proved that the word sart is inappropriate to be used as a common name for the indigenous people of Turkestan. While Behbudi analyzed his arguments for the word sart in this article, the author tried to explain it through various dictionaries, from the facts in historical books, to its meaning in the speech of nomadic peoples. This, in turn, shows that a great deal of research was done on the etymology of the word sart and Behbudi's ability in this regard.

After Behbudi cited all the evidences, in the end of the article he further noted that even the etymology of the word sart was abstract, and as the term sart was used to refer to sedentary people of Turkestan by nomadic Kazaks, he advised Russians to console with them to get some concrete answer on how to use the word properly.

The first article on the word sart in the Ayina was titled Sart So'zi Majhuldir (The word Sart is abstract) [13], the same as the article published in magazine Shura, and the second was published under the headline Sart So'zi Ma'lum Bo'lmadi (Origin of Word Sart Unknown)" [17]. In these articles, Behbudi analyzed the articles published by him and other authors in the magazine Shura on how to use the word correctly. Summarizing the views of all the authors, Behbudi wrote that the use of the term sart in reference to the settled population of Turkestan was an "insult'.

As proof of his point, Behbudi states that there were once upon a time Huns who conquered the whole Europe and they stayed in there for many more centuries to come before disappeared as a result of their mix with the local population, and he ask the question of whether it was appropriate to call Europeans as Huns or it was a kind of insult. As
Behbudi concludes his opinions, he stated that peoples in Europe take it as an insult when called Huns, he further mentioned that there was once upon a time a tribe called sart in the lands of Turkestan according to some history books, but referring to people as sart seems as an insult, he equated it to demean the nation.

\section{V.CONCLUSION}

Indeed, the ideas and works he wrote are of great importance in assessing the role of Behbudi in the Jadidism of Turkestan, his role in the spread of these movements, ideas and thoughts, his activities in the implementation of reforms in various spheres of socio-political life. In this sense, his views on (common) literary language, language norms, spelling, etymology of words, in a sense, allow us to make a certain assessment of Behbudi's work in the field of linguistics, to give an objective assessment of his actions in this direction.

Behbudi's excellent knowledge of the dialects of the Turkic language prevalent in Turkestan, his ability to periodize, evaluate and analyze the language of the periodicals published in the relatively advanced Turkic dialects of his time, proves that he was the first linguist among Turkestan intellectuals. Also, taking into account his research on their origin, the history of words we are given grounds to conclude that Behbudi was a scholar who was also the first to conduct research in the field of cultural anthropology in modern terms. In short, Behbudi is a linguist, sociologist, dialectologist, ethnographer, cultural anthropologist who worked effectively on the formation of the Uzbek language as a literary language.

\section{BIBLIOGRAPHY}

1. Khalid Adeeb. The politics of Muslim Cultural Reform: Jadidism in Tsarist Central Asia. Ph.D. diss., University of Wisconsin-Madison, 1993.

2. Komatsu Hisao. Muslim intellectuals and Japan: a Pan-Islamist mediator, Abdurreshid Ibrahim. In: Stephane A. Dudoignon, Komatsu Hisao, Kosugi Yasushi (eds.), Intellectuals in the Modern Islamic World: Transmission, Transformation, Communication. Routledge. 1999.

3. Baldauf, Ingeborg. $X X$ asr o'zbek adabiyotiga chizgilar. Toshkent: Ma'naviyat, 2001.

4. Dil, dil, dil // Tarjimon, 1905, № 103.

5. Ismoil. Umumiy lisoni adab // Tarjimon, 1906, № 37.

6. Istoriya obshestvenno-kul'turnogo reformatorstva na Kavkaze i v Sentral'noy Azii (XIX-nachalo XX veka). Samarkand: MISAI, 2012.

7. Qosimov, Begali. Milliy uyg'onish. Toshkent: Ma'naviyat, 2002.

8. Qosimov, Begali. Ismoil Gasprinskiy va Mahmudxo ‘ja Behbudiy. - Ismoil Gasprinskiy va Turkiston. Toshkent: Sharq, 2005.

9. Lison masalasi // Tarjimon, 1905, № 90. 
10. Mahmudxo'ja Behbudiy. Vahdati lison - dil birligi // Tarjimon, 1906, № 61.

11. Mahmudxo'ja bin Behbudxo'ja. Turkistonda maktab lisoni. // Tarjimon. 1909, №№ 14, 21.

12. Mahmudxo'ja. Ikki til emas to'rt til lozim // Oyina, 1913, № 1.

13. Mahmudxo'ja. Sart so'zi majhuldir // Oyina. 1914. № 22-26. - B.314-315; 338-340; 362-365; 386-388; 478-480

14. Mahmudxo 'ja. Til masalasi // Oyina, 1915, № 11-12.

15. Samarqand dorulqazo muftilaridan Mahmudxo 'ja bin Behbudxo 'ja. "Munozara" haqinda // Turkiston Viloyatining Gazeti. 1911. № 73.

16. Samarqanda muftiyi dorulqazo Mahmudxo 'ja bin Behbudxo'ja. Sart so'zi majhuldir // Sho'ro. 1911. № 19. - P.581-582.

17. Sart so 'zi ma'lum bo 'lmadi // Oyina. 1914. № 39. - P.922-924.

18. Haqiqat har tarafdan zuhur edar // Tarjimon, 1906, № 48.

19. Hoji Muin ibn Shukrulloh. Til birlashdurmaq haqqinda // Oyina. 1914. №11. 